\title{
Powdery Mildew Outbreak on Kale Caused by Erysiphe cruciferarum in Korea
}

\author{
Mi-Jeong Park ${ }^{1}$, Jin-Young Kim ${ }^{2}$, Jae-Gu Han ${ }^{1}$ and Hyeon-Dong Shin ${ }^{1 *}$ \\ ${ }^{1}$ Division of Environmental Science and Ecological Engineering, Korea University, Seoul 136-701, Korea \\ ${ }^{2}$ Gyeonggi-Do Agricultural Research \& Extension Services, Hwaseong 445-300, Korea \\ (Received on February 9, 2010; Accepted on March 19, 2010)
}

Kale (Brassica oleracea var. acephala) is widely cultivated for its edible leaves. The juice squeezed from fresh leaves and leaf stalks is very popular as health drink in Korea. As consumers willingly pay more to get organic kale, the farmers are cultivating the crop without pesticides and synthetic fertilizers. In February 2009, a severe outbreak of a previously unknown powdery mildew was found in plastic greenhouses in Sindun-myeon, Icheon, Korea. Heavily affected plantings were unmarketable and abandoned without harvesting (Fig. 1A). Symptoms first appeared as circular to irregular white colonies, which subsequently developed into abundant growth on both leaf surfaces (Fig. 1B \& C). The second outbreak of powdery mildew on organic kale was observed in Majang-myeon, Icheon, Korea. Two representative samples were deposited in the herbarium of Korea University (KUS-F24008, F24876).

Morphological characteristics of the powdery mildew fungus were examined. Appressoria on the mycelium were lobed. Conidiophores were unbranched, cylindrical, $88-140 \times 8-10 \mu \mathrm{m}$, composed of 3-4 cells (Fig. 1D). Conidia produced singly, were oblong to cylindrical oval, 32-60 $\times 13-18 \mu \mathrm{m}$, lacking distinct fibrosin bodies, with angular/rectangular wrinkling of outer wall (Fig. 1E \& F). No chasmothecia were found. The above structures are typical of the

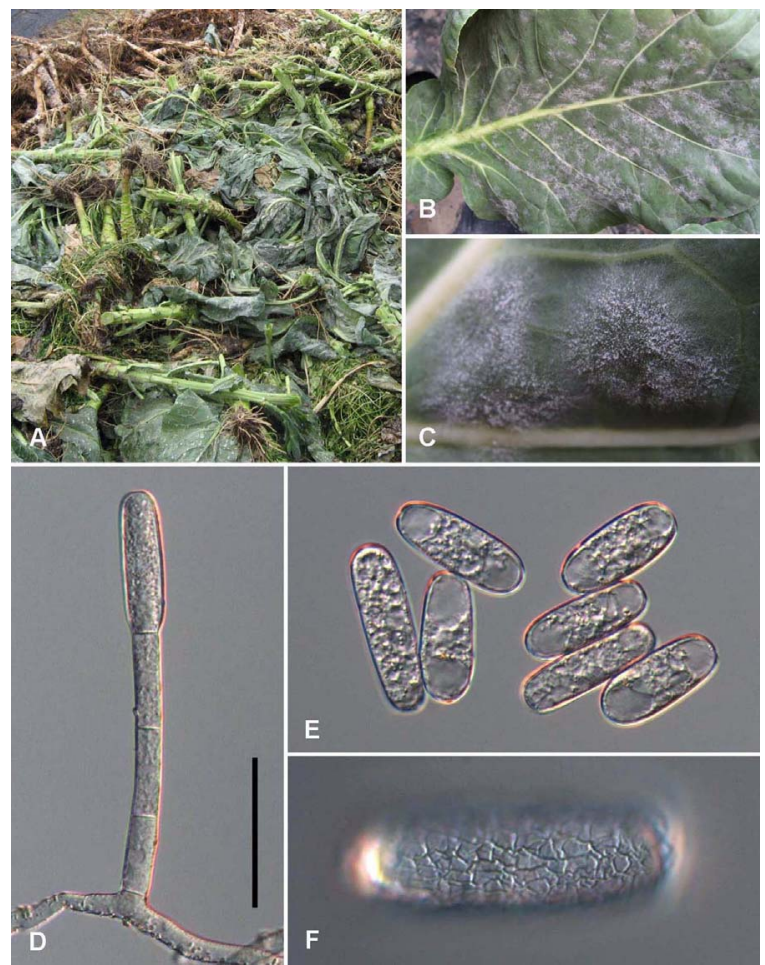

Fig. 1. (A) Piles of kale plants discarded due to powdery mildew infections. (B \& C) A kale leaf heavily infected with powdery mildew and a close-up of the lesions. (D-F) Conidiophore and conidia of Erysiphe cruciferarum. Note the angular/rectangular wrinkling pattern of outer wall of a conidium (F). $\mathrm{Bar}=50 \mu \mathrm{m}$ for $\mathrm{D} \& \mathrm{E}$ and $20 \mu \mathrm{m}$ for $\mathrm{F}$.
Oidium subgen. Pseudoidium anamorph of the genus Erysiphe, and the measurements of the present fungus are compatiblewith those of E. cruciferarum Opiz ex Junell described by Braun (1987).

To confirm the identity of the fungus, the complete ITS region of rDNA was amplified with primers ITS5 and P3 as described by Takamatsu et al. (2009) and directly sequenced. The resulting sequence of 561 bp was deposited in GenBank (GU721075). A phylogenetic tree (Fig. 2) was constructed using MEGA4 by neighbor-joining method with Tajima-Neidistance calculation. The obtained ITS sequence shared $99 \%$ similarity with the sequence of E. cruciferarum ex Brassicarapa var.rapa (EU 140958). Therefore, the molecular analysis confirmed that the fungus is identified as $E$. cruciferarum.

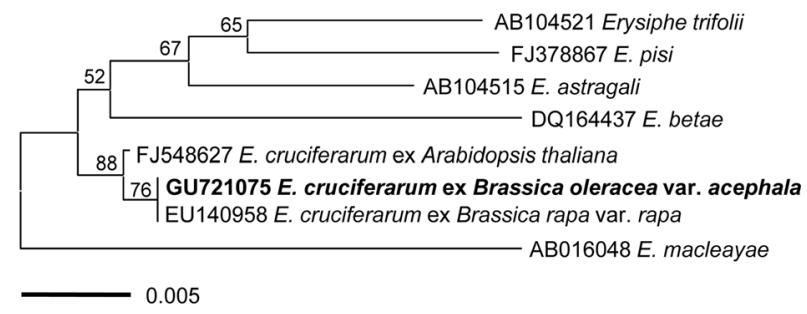

Fig. 2. Phylogenetic tree showing relationship between Erysiphe cruciferarum on Brassica oleracea var. acephala and other Erysiphe species, inferred by neighbor-joining method using the ITS rDNA region. Numbers above the branches represent the bootstrap values. Bar=Number of nucleotide substitutions per site.

The powdery mildew fungi occurring on kale were recorded from Europe (Belarus, Germany) and South Africa as E. cruciferarum, and also from Europe (Portugal, Yugoslavia) and Brazil as Oidium sp. (Farr and Rossman, 2010). Recently, anamorph of E. cruciferarum was found on decorative kale in Japan (Tanda et al., 1999). There has been no previous record on powdery mildew infection of kale in Korea. This is the first report of powdery mildew outbreak on kale with economic losses in the world. Since most of kale plants are cultivated year-round for producing leaves, powdery mildew lesions on leaves pose a serious threat to quality and marketability in winter season.

\section{References}

Braun, U. 1987. A Monograph of the Erysiphales (Powdery Mildews). Beihefte zur Nova Hedwigia 89:1-700.

Farr, D. F. and Rossman, A. Y. 2010. Fungal Databases, Systematic Mycology and Microbiology Laboratory, ARS, USDA. Retrieved February 5, 2010, from http://nt.ars-grin.gov/fungaldatabases/

Takamatsu, S., Heluta, V., Havrylenko, M. and Divarangkoon, R. 2009. Four powdery mildew species with catenate conidia infect Galium: molecular and morphological evidence. Mycol. Res. 113:117-129.

Tanda, S., Morita, A. and Motooka, K. 1999. Powdery mildews on some herbaceous flowering and vegetable plants which were introduced into Japan and their causal fungi.J. Agric. Sci-Tokyo Univ. Agric. 44:115-131.

*Corresponding author (hdshin@korea.ac.kr) 